\title{
ENHANCEMENT OF GAMMA-LINOLENIC ACID PRODUCTION BY THE FUNGUS MUCOR SP LB-54 BY GROWTH TEMPERATURE
}

\author{
Patrícia de Oliveira Carvalho $^{{ }^{*}}$; Joaquim Gilberto de Oliveira $^{2}$; Gláucia Maria Pastore ${ }^{2}$ \\ ${ }^{1}$ Faculdade de Ciências Farmacêuticas, Universidade São Francisco, Bragança Paulista, SP, Brasil. \\ ${ }^{2}$ Departamento de Ciência de Alimentos, Faculdade de Engenharia de Alimentos-FEA, Universidade \\ Estadual de Campinas-UNICAMP, Campinas, SP, Brasil.
}

\begin{abstract}
As a relatively prolific producer of GLA, the strain of Mucor sp LB-54 was selected for a study at different growth temperatures in shaker flask culture. The strain used in our experiment was capable to accumulate a relatively high amount of intracellular lipid, $20.73 \%$ of dry cell weight, and GLA content of $15 \%$ of total fatty acids after 5 days of incubation at $28^{\circ} \mathrm{C}$. As the growth temperature was decreased from 28 to $12^{\circ} \mathrm{C}$ the percentage of GLA increased from 15 to $24 \%$ of total fatty acids. In order to optimize the culture conditions for rapid biomass production and lipid production with a high proportion of GLA, the fungus was grown at two temperature combinations associated supplies of carbon source (glucose) in the culture medium. Maximal production of GLA $(74 \mathrm{mg} / \mathrm{l})$ was obtained from the Mucor sp LB-54 strain after 5 days of incubation at $28^{\circ} \mathrm{C}$ in basal medium following glucose addition $(7 \% \mathrm{w} / \mathrm{v})$ and incubation for an additional 3 days at $12^{\circ} \mathrm{C}$. The identity of GLA found in the strain of Mucor sp LB-54 was confirmed by the coupled gas chromatography-mass spectrometry
\end{abstract}

Key words: Gamma-linolenic acid, Mucor sp, unsaturated fatty acids

\section{INTRODUCTION}

Gamma-linolenic acid (GLA, 6,9,12octadecatrienoic acid) is an important intermediate in the biosynthesis of biologically active prostaglandin from linolenic acid. GLA has been reported to be effective for the prevention or curing of cardiovascular diseases (10), hypercholesterolemia (11), menstrual disorders (16), for applications in curing certain skin-related (19), as well as a variety of other diseases (3).

At the present time, GLA is commercially produced from the seeds of evening primrose
(Oenothera biennis) and boragem (Borago oficinallis). However, the productivity of GLA from the seed oil is extremely low, since both a long period and a huge area for harvesting seed are required (8). To overcome these problems, microorganisms have been investigated as an alternative GLA source and some suitable strains have been proposed. Mortierella ramanniana (9), Mucor sp (21), Cunninghamella japonica (7), and Entomophthora exitalis (13) were reported as perspective GLA producers. Currently, only Japan is producing GLA commercially, using the fungus Mortierella (17).

There is sufficient information in the literature

\footnotetext{
* Corresponding author. Mailing address: Rua Santo Monte, 65, Jardim Salessi, CEP 129000-000, Itatiba, SP, Brasil. Fax: (+5511) $7806-8040$
} 
on the fatty acid composition of fungi to warrant a statement that Phycomycetes are characterized in their ability to synthesize GLA, whereas the members of Ascomycetes and Basidiomycetes, with a few exceptions, produce alfa linolenic acid (20). Most of these investigations were carried out to determine the fatty acid composition of different fungi and to compare them with other groups of organisms to obtain information on their phylogenetic relationships.

In the preceding paper (5) we reported a strain of Mucor sp screened in our laboratory would be a promising producer of GLA. Therefore, further works on the optimization of fermentation process are needed in order to increase the productivity of GLA. The temperature is the principal regulation factor of the degree of unsaturated in the lipids of this organism (4). In many species of fungi there is a pronounced influence of growth temperature on the biosynthesis of unsaturated fatty acids. In general, organisms grown under low temperature conditions possess a relatively high degree of unsaturation in their lipids, presumably as a part of the adaptive response to the cold environment (15).

This paper deals with the effects of growth temperature for the fungal growth, lipid and GLA contents in cellular lipid of Mucor sp LB-54 with an emphasis on GLA productivity.

\section{MATERIALS AND METHODS}

\section{Strain}

The fungal strain used in this study was designated Mucor sp LB 54 by Biochemistry Laboratory at State University of Campinas, Brazil (5). The pure cultures of fungi were stored on PDA slants and kept at $4^{\circ} \mathrm{C}$ until used.

\section{Medium and culture conditions}

The basal medium for fungal growth and GLA production is the same as in the previous paper containing glucose, $20 \mathrm{~g} / \mathrm{l}$ and yeast extract, $10 \mathrm{~g} / \mathrm{l}$ (5). $50 \mathrm{ml}$ Erlenmeyer flask containing $25 \mathrm{ml}$ of culture medium was inoculated with spore suspension at the final concentration of $7.10^{7}$ spores per millilitre of cultivation medium. The initial $\mathrm{pH}$ of the medium was adjusted to 7.0 and liquid cultures were grown on a rotative shaker at 120 strokes per min for 1- 15 days. To study the effects of growth temperature on GLA production, mycelia were incubated at each temperature ranging from 5 to $40^{\circ} \mathrm{C}$.

\section{Measurement of dry cell weight and total lipid}

The mycelia fungi were separated by centrifugation $\left(15,000 \mathrm{rpm}\right.$ for $15 \mathrm{~min}$ at $\left.10^{\circ} \mathrm{C}\right)$ and the harvested fungi were washed twice with destined water. The dry cell weight was determined by drying the cells with acetone and in a vacuum oven to constant weight at $40^{\circ} \mathrm{C}$. Before extraction of the lipids, the biomass was pulverized. The lipids were extracted from the dried biomass with chloroform/ methanol/water (2).

\section{Analysis of fatty acid composition}

The lipids were saponified with $0.5 \mathrm{M} \mathrm{NaOH}$ and esterified with methanol- $\mathrm{BF}_{3}(1)$. The fatty acids methyl esters (FAME) were analyzed by gas chromatography in a Chrompack CG instrument equipped with flame ionisation detectors (FID). The separations were carried out on a $50 \mathrm{~m} \times 0.25 \mathrm{~mm}$ fused silica WCOT CP-Sil 88 capillary column (Chrompack, Holland) using temperature programme of $180-220^{\circ} \mathrm{C}$, $5^{\circ} \mathrm{C} / \mathrm{min}$; hydrogen was used as carrier gas. FAME were identified by comparing retention times with those of authentic standards (Sigma Chemical Co.) and determined by relative percentage. GLA was confirmed by the coupled gas chromatography-mass spectrometry (Hewlett-Packard 5890).

\section{RESULTS AND DISCUSSION}

In Fig. 1 the data obtained for the determination of growth of Mucor sp LB-54 at temperature ranging from 5 to $40^{\circ} \mathrm{C}$ are summarized. The results show that Mucor sp LB-54 is a slightly mesophilic fungus and that the minimum, optimum and maximum temperatures for growth are 8,28 and $38^{\circ} \mathrm{C}$ respectively. It was also noted that the cultures grown at $28^{\circ} \mathrm{C}$ achieved maximum growth within 5 days, whereas at temperatures above or below this optimum, it took 10 days or more.

For further investigation on the biomass and lipid content, growth temperatures of 12,28 and $38^{\circ} \mathrm{C}$ were selected since growth was negligible below $10^{\circ} \mathrm{C}$ and above $38^{\circ} \mathrm{C}$. The culture was incubated for 5 days and then the production of GLA was studied. The data in Table 1 show the strain of Mucor sp LB-54 produced relatively high cell weight and total lipids when grown at $28^{\circ} \mathrm{C}$. The yield of lipids was $20.7 \%$ of dry cell weight of the culture, which mean the maximal concentration of $44 \mathrm{mg}$ of GLA per liter of culture medium. Although the lipids of culture grown at $12^{\circ} \mathrm{C}$ showed the highest GLA 


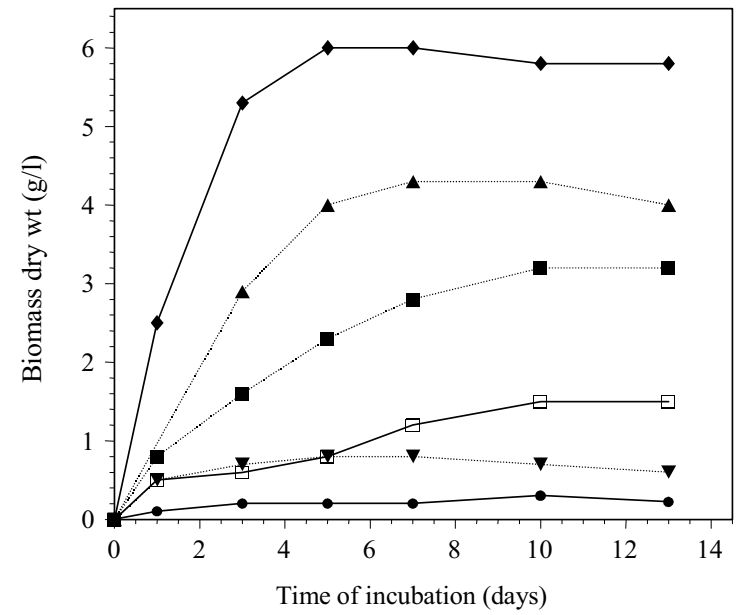

Figure 1. Growth of Mucor sp LB-54 on basal medium as a function of time at temperatures ranging from 5 to $45^{\circ} \mathrm{C}$. The incubation temperatures $\left({ }^{\circ} \mathrm{C}\right)$ are: $5=\bullet \bullet \bullet, 8=\square-\square, 12=\mathbf{\square - -}$ $28=\bullet, 38=\boldsymbol{\Delta}--\mathbf{\Delta}, 45=\boldsymbol{\nabla}---\nabla$. Each point is the mean of three repetitions.

content, about $24 \%$ of total fatty acids, that seem not suitable for the production of GLA because of low lipid yield ( $15.8 \%$ of dry cell weight).

The degree of unsaturation in the fatty acid composition is known to be influenced by temperature, i. e. when the growth temperature is lowered the proportion of unsaturated acids tend to increase. An earlier study with fungus has shown that there was increased production of GLA at low growth temperature with a corresponding increase in the degree of unsaturation of total lipids (6).

The temperature did not only influence growth and lipid production; it also affected the cell morphology. At $38^{\circ} \mathrm{C}$ big fluffy pellets were formed (10 $\mathrm{mm}$ in diameter) during the first $24 \mathrm{~h}$, and then the pellets were transformed into mycelia that tended to clump. The mycelium formation was avoided by running the cultures at $28^{\circ} \mathrm{C}$ and $12^{\circ} \mathrm{C}$, where stable pellets were formed; the pellets decreased in diameter with decreasing temperature $(0.5 \mathrm{~mm}$ and $0.3 \mathrm{~mm}$, respectively). This minute size of pellets would give a great advantage in the large scale and high-density cultivation of fungi when the mass transfers problems of filamentous fungal growth.

The Fig. 2 shows the time course of the main fatty acids contents in the total lipid fraction of Mucor sp LB-54 grown at 12,28 and $35^{\circ} \mathrm{C}$. The major fatty acids common to three growth temperatures and incubation periods were palmitic acid (16:0), stearic acid (18:0), oleic acid (18:1), linoleic acid (18:2) and GLA (18:3). A small part, about $2-4 \%$ of the lipid fraction consisted of other fatty acids, myristic acid (C14:0), palmitoleic acid (C16:1) and stearic acid (18:0). The analysis of fatty acids revealed an insignificant content of fatty acids with an odd number of carbon atoms $(<1 \%)$ and the complete absence of the alfa-isomer (alfa linolenic acid). It is also evident that at the lower temperature there was an increase in the amount of linoleic acid and GLA with a corresponding decrease palmitic acid and oleic acid. A temperature decrease to $12^{\circ} \mathrm{C}$ resulted in an increase in percent composition of GLA for $24 \%$ of total fatty acids. The percent composition of other fatty acids did not vary appreciably under the influence of different temperatures.

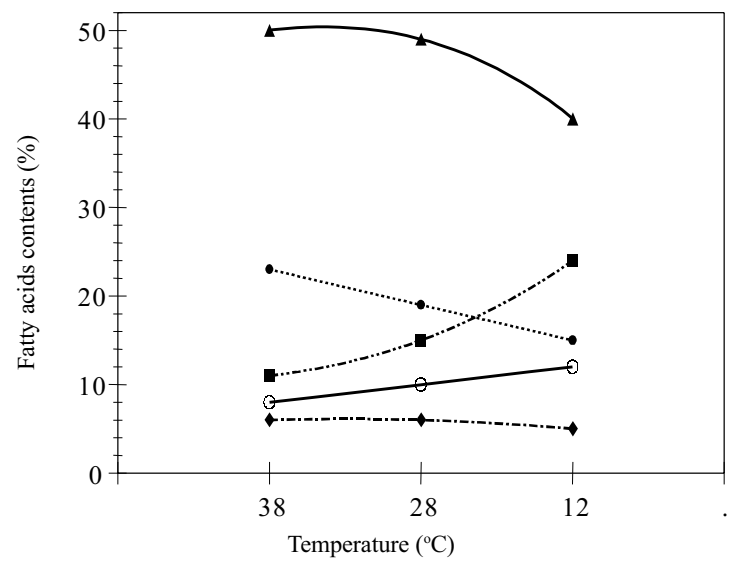

Figure 2. Changes the main fatty acids contents in lipid produced by Mucor sp LB-54 as a function of growth temperature. The fatty acids contents were expressed relative percentage of total fatty acids. Palmitic acid (16:0) = $\bullet---\bullet$, Stearic acid $(18: 0)=$ $\bullet--$, Oleic acid $(18: 1)=\boldsymbol{\Delta}-\boldsymbol{\Lambda}$, Linoleic acid $(18: 2)=0-0$, $\gamma$-Linolenic acid $(18: 3)=-$---m. Each point is the mean of three repetitions.

Table 1. Effect of growth temperature on total lipid, biomass contents and production of GLA by Mucor sp LB-54.

\begin{tabular}{cccccc}
\hline $\begin{array}{c}\text { Temperature } \\
\left({ }^{\circ} \mathrm{C}\right)\end{array}$ & $\begin{array}{c}\text { Biomass } \\
(\mathrm{g} / \mathrm{l})\end{array}$ & $\begin{array}{c}\text { Lipid } \\
(\mathrm{g} / \mathrm{l})\end{array}$ & $\begin{array}{c}\text { Total lipid/dry } \\
\text { weight }(\% \mathrm{w} / \mathrm{w})\end{array}$ & $\begin{array}{c}\text { GLA/total } \\
\text { fattyacids }(\% \mathrm{w} / \mathrm{w})\end{array}$ & GLA (mg/l) \\
\hline 12 & 2.47 & 0.39 & 15.84 & 24.02 & 23.40 \\
28 & 5.83 & 1.21 & 20.73 & 14.68 & 43.97 \\
38 & 4.29 & 0.49 & 11.42 & 11.66 & 22.90 \\
\hline
\end{tabular}


The results of this study show that the lower growth temperatures simulate the biosynthesis of highly unsaturated fatty acids, a phenomenon that has already been observed for some mesophilic and psychrophilic Mucor species (22). The effects of temperature on the degree of lipid unsaturation may be exerted through the influence of temperature on oxygen tension of the media. Oxygen is a necessary cofactor in enzymatic desaturation, resulting in lower levels of unsaturated fatty acids as temperature increases (15). The conversion of saturated into unsaturated fatty is known to be regulated by desaturase enzymes which require oxygen as a cofactor together with acetyl coenzyme A (acetyl CoA), acyl carrier protein (ACP), reduced nicotinamide adenine dinucleotide $\left(\mathrm{NADH}_{2}\right)$ and reduced nicotinamide adenine dinucleotide phosphate $\left(\mathrm{NADPH}_{2}\right)$ (13). Accumulation of unsaturated fatty acids at low temperature could to be a resources used for the increased biosynthesis of GLA by Mucor sp LB-54.

To confirm the GLA peak obtained from the cellular lipids of Mucor sp LB-54, a mass spectrometric analysis was applied. Fig. 3 shows a molecular ion peak at $\mathrm{m} / \mathrm{e} 292$ and intense fragment ion peak at m/e 93, 79, 67 and 41. Each peak is in good accord with the corresponding one of the authentic standard.

In order to combine the beneficial effects of rapid biomass production and a high production of GLA by Mucor sp LB-54, we tested the effect at two temperature combinations associated additional of glucose. Table 2 shows the results of the five culture conditions in shaker culture on total lipid, biomass contents and GLA production of Mucor sp LB-54.

When the culture was started at $28^{\circ} \mathrm{C}$ and the temperature was changed to $12^{\circ} \mathrm{C}$, the proportions of GLA of total fatty acids increased (15.90\%), moreover, occurs the depletion tendency of lipid with culture time (Condition 2). This agree with the others reported $(14,23)$ indicating that the accumulated lipids are used as a carbon and energy supply by fungi when glucose to become exhaustion.

On the other hand, cultures with glucose added was possible to achieve both a high final lipid content and a reasonably good production of GLA by Mucor sp LB-54. Optimal production of GLA was obtained by incubating first for 5 days at $28^{\circ} \mathrm{C}$ in a basal

A

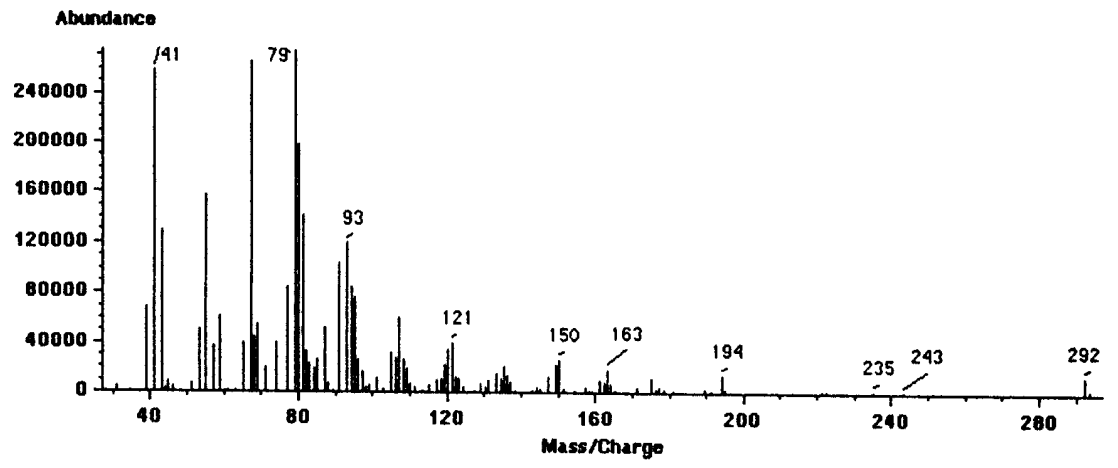

B

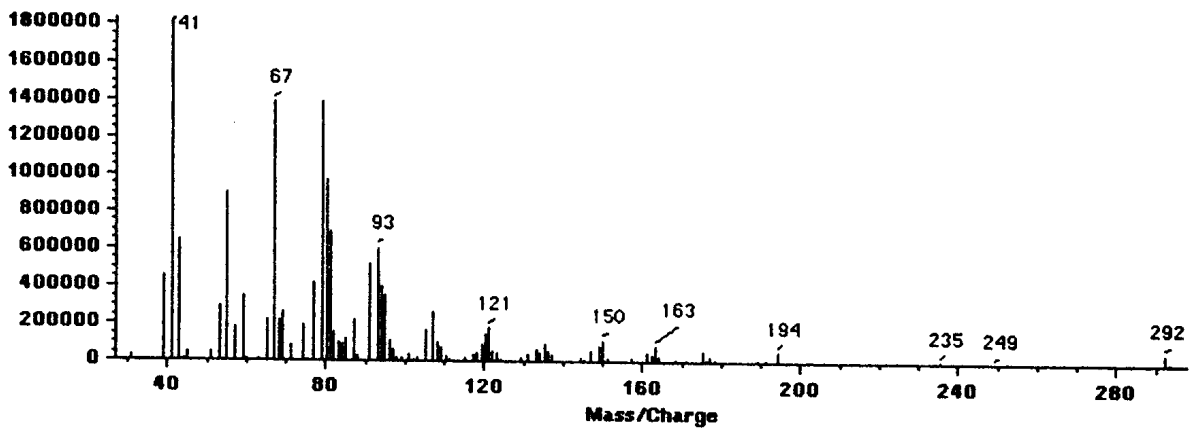

Figure 3. Mass spectra of authentic standards of GLA (A) and C18:3 acid methyl ester from cellular lipids of strain Mucor sp LB-54 (B). 
Table 2. Effect of growth temperature and glucose addition on total lipid, biomass contents and production of GLA by Mucor sp LB-54

\begin{tabular}{cccccc}
\hline $\begin{array}{c}\text { Incubation } \\
\text { conditions }\end{array}$ & $\begin{array}{c}\text { Biomass } \\
(\mathrm{g} / \mathrm{l})\end{array}$ & $\begin{array}{c}\text { Lipid } \\
(\mathrm{g} / \mathrm{l})\end{array}$ & $\begin{array}{c}\text { Total lipid/ } \\
\text { dry weight }(\% \mathrm{w} / \mathrm{w})\end{array}$ & $\begin{array}{c}\text { GLA/ total fatty } \\
\text { acids }(\% \mathrm{w} / \mathrm{w})\end{array}$ & $\begin{array}{c}\text { GLA } \\
(\mathrm{mg} / \mathrm{l})\end{array}$ \\
\hline 1 & 5.83 & 1.21 & 20.73 & 14.68 & 43.97 \\
2 & 6.03 & 0.96 & 15.71 & 15.90 & 37.34 \\
3 & 5.47 & 1.28 & 23.47 & 17.17 & 54.69 \\
4 & 6.27 & 1.57 & 25.07 & 19.40 & 74.10 \\
5 & 6.33 & 1.22 & 19.15 & 18.35 & 55.33 \\
\hline
\end{tabular}

1: 5 days at $28^{\circ} \mathrm{C}$ in basal medium

2: 5 days at $28^{\circ} \mathrm{C}$ in basal medium following incubation for 3 days at $12^{\circ} \mathrm{C}$ (not addition glucose)

3: 5 days at $28^{\circ} \mathrm{C}$ in basal medium following glucose addition $(3 \% \mathrm{w} / \mathrm{v})$ and incubation for 3 days at $12^{\circ} \mathrm{C}$.

4: 5 days at $28^{\circ} \mathrm{C}$ in basal medium following glucose addition $(7 \% \mathrm{w} / \mathrm{v})$ and incubation for 3 days at $12^{\circ} \mathrm{C}$.

5: 5 days at $28^{\circ} \mathrm{C}$ in basal medium following glucose addition $(10 \% \mathrm{w} / \mathrm{v})$ and incubation for 3 days at $12^{\circ} \mathrm{C}$.

medium and then supplementing with extra glucose $(7 \% \mathrm{w} / \mathrm{v})$ followed by additional incubation for 3 days at $12^{\circ} \mathrm{C}$ (Condition 3). Using a relatively high initial growth temperature for biomass production, and glucose feeding followed by a temperature shift to $12^{\circ} \mathrm{C}$, GLA production by Mucor sp LB-54 was enhanced to $74 \mathrm{mg}$ of GLA per liter of culture medium, corresponding to 1.7 fold enrichment of GLA. This is mainly due GLA content of $19.40 \%$ of the total fatty acids associated the increased to the content of lipid $25.07 \%$ in dry cell which is higher than the baseline cultures (Condition 1).

Certain species of Mucor are capable of producing relatively large quantities of GLA. For example, Mucor circinelloides grown at $30^{\circ} \mathrm{C}$ with acetic acid as carbon source produced 90 - 120 $\mathrm{mg} \mathrm{GLA}^{-1}$ (18) and strain of Mucor sp KCTC 8405P isolated in Korea cultured on $3 \%$ glucose and $0.1 \%\left(\mathrm{NH}_{4}\right)_{2} \mathrm{SO}_{4}$ produced about $14 \%(\mathrm{w} / \mathrm{w})$ of GLA in total lipids (12).

With this strategy, we were able to stimulate GLA production by of Mucor sp LB-54 from the baseline level of about $44 \mathrm{mg} \mathrm{l}^{-1}$ to $74 \mathrm{mg} \mathrm{l}^{-1}$. The data presented in this paper show the significant influence which incubation temperature and supply glucose exerts on the GLA production by Mucor sp LB-54. Presumably, it is not the temperature, as such, that affects the unsaturated fatty acids but the solubility of $\mathrm{O}_{2}$, which increases at decreasing temperatures (13). These results suggest that Mucor sp LB-54 may have potential for commercial development for the production of GLA by fermentation techniques.

\section{ACKNOWLEDGEMENTS}

This work was supported by the Fundação de Amparo à Pesquisa de São Paulo (FAPESP) of Brazil.

\section{RESUMO}

\section{Aumento da produção de ácido gama linolênico por fungo Mucor sp LB-54 de acordo com a temperatura de cultivo}

A linhagem de Mucor sp LB-54, considerada uma potencial produtora de ácido gama-linolênico (GLA), foi selecionada para o estudo de diferentes temperaturas de cultivo em agitador rotativo. A linhagem usada neste experimento era capaz de acumular uma quantidade alta de lipídeos intracelulares, $20,73 \%$ do peso seco de biomassa e conteúdo de GLA de $15 \%$ dentre os ácidos graxos totais de sua constituição após 5 dias de incubação à $28^{\circ} \mathrm{C}$. Quando a temperatura de cultivo foi diminuída de $28^{\circ} \mathrm{C}$ para $12^{\circ} \mathrm{C}$, o conteúdo de GLA aumentou de 15 para $24 \%$ dentre os ácidos graxos totais de sua constituição. Com o objetivo de otimizar as condições de cultivo para a produção rápida de biomassa e produção de lipídeos contendo conteúdo alto de GLA, o fungo foi cultivado em duas combinações de temperaturas associadas com a suplementação de fonte de carbono (glicose). A produção máxima de GLA ( $74 \mathrm{mg} / \mathrm{l})$ pela linhagem de Mucor sp LB-54 foi obtida após 5 dias de incubação à $28^{\circ} \mathrm{C}$ em meio base, seguida da adição de glicose $(7 \% \mathrm{p} / \mathrm{v})$ no meio de cultura e uma posterior incubação por mais 3 dias a $12^{\circ} \mathrm{C}$. A identidade do GLA foi confirmada pelo sistema acoplado cromatógrafo à gás - espectrômetro de massa.

Palavras-chave: ácido gama-linolémico, Mucor sp, ácidos graxos insaturados 


\section{REFERENCES}

1. AOCS. Official and Tentative of the American Oil Chemists Society. Walker, R. O. 3rd ed., American Oil Chemists' Society, Champaign, Method $\mathrm{N}^{\circ}$ Ce 2-66, 1978.

2. Bligh, E. G.; Dyer, J. W. A rapid method of total lipid extraction and purification. Can. J. Biochem. Physiol., 37:911-917, 1959

3. Carter, J. P. Gamma-linolenic acid as a nutrient. Nutritional supplements containing gamma-linolenic acid may safely ameliorate certain health problems. Food Technol., 1:72-83, 1988.

4. Carvalho, P. O. Produção de Ácido Gama Linolênico por nova linhagem de Mucor sp e estudo das condições de fermentação. Campinas, 1994.129p. Tese (Mestrado Faculdade de Engenharia de Alimentos, UNICAMP).

5. Carvalho, P. O.; Silva, M. T. C.; Park, Y. K.; Pastore, G. M. Produção de ácido gama-linolênico por novas linhagens de microorganismos. Ciênc. Tecnol. Alim., 35:579-584, 1991.

6. Devem, J. M.; Manocha, M. S. Effect of various cultural conditions on the fatty acid and lipid composition of Choanephora cucurbitarum. Can. J. Microb., 22:443-449, 1976.

7. Galanina, L. A.; Bekhtereva, M. N.; Pavlova, T. A.; Tsvetkova, E. V. Utilization of individual monosaccharides from their mixtures by the microscopic fungus Cunninghamella japonica and its effect on lipid synthesis. Mikrobiologiya 57, 213-217, 1988.

8. Gunstone, F. D. Gamma linolenic acid - occurrence and physical chemical properties. Prog. Lip. Res., 31:145-161, 1992.

9. Hansson, L.; Dostálek, M. Effect of culture conditions on mycelial growth and production of $\gamma$-linolenic acid by the fungus Mortierella ramanniana. Appl. Microb. Biotechnol., 28:240-246, 1988

10. Horrobin, D.F.; Huang, Y.S. The role of linoleic acid and its metabolites in the lowering of plasma cholesterol and the prevention of cardiovascular disease. Int. J. Cardiol., 17:241$255,1987$.
11. Horrobin, D.F.; Manku, M. S. How do polyunsaturated fatty acids lower plasma cholesterol levels? Lipids, 18:558-562, 1983.

12. Kang, H.S.; Shin, H.D. Influence of medium composition on the production of $\gamma$-linolenic acid by Mucor sp KCTC 8405P. Kor. J. Appl. Microbiol. Bioeng., 17:568-573, 1989.

13. Kendrick, A.; Ratledge, C. Lipid formation in ther oleaginous mould Entomophthora exitalis grown in continuous culture: effects of growth rate, temperature and dissolved oxygen tension on polyunsaturated fatty acids. Appl. Microbiol. Biotechnol., 37:18-22, 1992a.

14. Kendrick, A.; Ratledge, C. Lipids of selected molds grown for production of $n-3$ and $n-6$ polyunsaturated fatty acids. Lipids, 27:15-20, 1992b.

15. Neidleman, S. L. Effects of temperature on lipid unsaturation. Biotechnol. Genet. Eng. Ver., 5:245-268, 1987.

16. Puolakka, J.; Mäkäräinen, L.; Viinikka, L.; Ylikorkala, O. Biochemical and clinical effects of treating the premenstrual syndrome with prostaglandin synthesis precursors. J. Reprod. Med., 30:149-153, 1985.

17. Ratledge, C. Single cell oils - have they a biotechnological future? Trends Biotech., 11:278-284, 1993.

18. Roux, M. P.; Kock, J. L. F.; Botha, A.; Du Preez, J. C.; Wells, G. V.; Botes, P. J. Mucor - a source of cocoa butter and gamma-linolenic acid. World J. Microbiol. Biotechol., 10:417-422, 1994.

19. Schalin-Karrila,M.; Mattila, L.; Jansen, C.T; Uotila, P. Evening primrose oil in the teatment of atopic eczema: effect on clinical status, plasma phospholipid fatty acid and circulating blood prostaglandins. Br. J. Dermat., 117:11-19, 1987.

20. Shaw, R. The occurrence of $\gamma$-linolenic acid in fungi. Biochim. Biophys. Acta, 98:230-237, 1966.

21. Shin, Y.C.; Shin, H.K. Screening of $\gamma$-linolenic acid-producing fungi. Kor. J. Food Sci. Tecnol. 20:724-731, 1988.

22. Sumner, J. L.; Morgan, E.D.; Evans, H.C. The effect of growth temperature on the fatty acids composition of fungi in the order Mucorales. Can. J. Microbiol., 15:515-520, 1969.

23. Wassef, M. F. Fungal lipids. Adv. Lip. Res., 15:159-232, 1977. 